\title{
Reliability, Stability and Validity of the Brazilian Adaptation of the Oliveira Questionnaire on Low Back Pain in Young People
}

\section{Fiabilidade, Estabilidade e Validade da Adaptação Brasileira do Questionário Oliveira para Dor Lombar em Jovens}

\author{
Debora Soccal SCHWERTNER $\square^{1,2}$, Raul OLIVEIRA ${ }^{1}$, Ana Paula Ramos MARINHO ${ }^{3}$, Magnus BENETTI ${ }^{3}$, \\ Thais Silva BELTRAME ${ }^{3}$, Renata CAPISTRANO ${ }^{3}$ \\ Acta Med Port 2017 Oct;30(10):691-698 - https://doi.org/10.20344/amp.8270
}

\section{ABSTRACT}

Introduction: The objective of this study was to adapt the Brazilian version, and verify the validity, reliability and internal consistency of the Oliveira questionnaire on low back pain in young people.

Material and Methods: The questionnaire was translated from European Portuguese into Brazilian Portuguese by means of translation and re-translation. The validity of the contents was determined by experts who analyzed the clarity and pertinence of the questions. Fifteen young people aged 15 to 18 took part in the pre-test step (qualitative analysis), 40 in the test-retest (reliability) and 679 in the evaluation of internal consistency. The intra-class correlation coefficient and Spearman's correlation coefficient were used in the reliability analysis (test-retest), and Cronbach's alpha to determine the internal consistency (stability).

Results: In the translation phase the questionnaire was modified and considered suitable, observing similarity and equivalence of the two versions. After being corrected by the experts in the validation of the contents, the instrument was considered suitable and valid, and in the pre-test, the young people suggested some modifications to make the questionnaire more succinct. With respect to reliability, the values for the intra-class correlation coefficient were between 0.512 - acceptable and 1 - excellent and Spearman's correlation coefficient varied between 0.525 and 1 , classifying the instrument as reproducible. The internal consistency was considered acceptable with a 0.757 Cronbach's alpha.

Discussion: The Oliveira questionnaire was choosen since it has been used in several Portuguese studies; moreover, it addresses the need to raise data regarding low back pain and associated risk factors.

Conclusions: The Brazilian version of the Oliveira questionnaire on low back pain in young people showed valid and reliable cultural adaptation, with good reliability and stability.

Keywords: Adolescent; Brazil; Low Back Pain; Pain Measurement; Reproducibility of Results; Surveys and Questionnaires; Validation Studies

\section{RESUMO}

Introdução: O objectivo deste estudo foi adaptar a versão brasileira, verificar a validade, a fiabilidade e a consistência interna do questionário de Oliveira para dor lombar em jovens.

Material e Métodos: A tradução do questionário do português de Portugal para o português do Brasil foi realizado através de tradução e re-tradução. A validade de conteúdo foi realizada por experts que analisaram a clareza e pertinência das questões. Participaram das etapas de pré-teste 15 jovens (análise qualitativa), teste-reteste 40 jovens (fiabilidade) e avaliação da consistência interna 679 jovens com idade de 15 a 18 anos. Na análise da fiabilidade (teste-reteste) usou-se o coeficiente de correlação intra-classe e o coeficiente de correlação de Spearman, na consistência interna (estabilidade) o alpha de Cronbach.

Resultados: Na fase de tradução o questionário foi modificado e considerado adequado, observando-se similaridade e equivalência nas duas versões. Na validação de conteúdo, após as correções dos peritos, o instrumento foi considerado adequado e válido. Os jovens no pré-teste sugeriram modificações tornando o questionário mais sucinto. Quanto a fiabilidade, os valores para o coeficiente de correlação intraclasse foram de 0,512 - aceitável a 1 - excelente, o coeficiente de correlação de Spearman variou entre 0,525 a 1; estes valores classificam o instrumento como reprodutível. A consistência interna foi considerada aceitável alpha de Cronbach de 0,757 . Discussão: O questionário Oliveira foi escolhido por ter sido utilizado em vários estudos em Portugal; além disso, atende a necessidade de levantar dados sobre dor lombar e fatores de risco associados.

Conclusão: A versão brasileira do questionário de Oliveira para dor lombar em jovens tem adaptação cultural válida e fiável, com boa confiabilidade e estabilidade.

Palavras-chave: Adolescente; Brasil; Dor Lombar; Estudos de Validação; Inquéritos e Questionários; Medição da Dor; Reprodutibilidade dos Resultados

\section{INTRODUCTION}

Low back pain is a complaint that is more and more common amongst young people, and its prevalence tends to increase with age up to 17 years of age, which is when and economic repercussions, ${ }^{2-4}$ related to absenteeism at classes/work, decrease in physical activity, disabilities and health costs..$^{1,2,5}$ it becomes similar to that of adults. ${ }^{1}$ It has personal, social

Early detection of these complaints is very important, ${ }^{6}$

1. Laboratory of Motor Behavior. Faculdade de Motricidade Humana. Universidade de Lisboa. Lisboa. Portugal.

2. Department of Physiotherapy. Universidade do Estado de Santa Catarina. Florianópolis. Brasil.

3. Postgraduate Program in Human Science Movement. Center of Health Sciences and Sport. Universidade do Estado de Santa Catarina. Florianópolis. Brasil.

$\triangle$ Autor correspondente: Debora Soccal Schwertner. debora.soccal@udesc.br

Recebido: 05 de outubro de 2016 - Aceite: 08 de junho de 2017 | Copyright $\odot$ Ordem dos Médicos 2017 
since not only is low back pain in adolescence being an important predictor of the same complaint in adulthood, ${ }^{7}$ but also the approach to chronic low back pain is more complex and has a greater number of associated co-morbidities. ${ }^{6}$ Thus many studies have been carried out in order to analyze the prevalence/ incidence of low back pain in young people and the different associated risk factors, ${ }^{4,8}$ but there is still no consensus concerning the elements that contribute to the appearance of the complaint and how they interact. 9,10 In order to decrease divergences between the results of different studies, in first place the instruments used must be reliable and internationally standardized, ${ }^{11,12}$ in order to be possible to discuss the differences that occur, for example, in terms of cultural behavior rather than methodologies. ${ }^{12,13}$ The questionnaire is the most used instrument for this type of survey, since the evaluation of pain is based on individual subjective perception. ${ }^{14,15}$ This evaluation instrument allows one to raise various dimensions of the problem, is of low cost, can be applied to large populations ${ }^{16}$ and allows one to accompany the evolution of the pain both in individuals and in groups. ${ }^{17}$ Although widely used, questionnaires are developed for specific studies, and there are only a few instruments internationally validated and applied to evaluate the prevalence of back pain and its associated risk factors. ${ }^{18}$ Considering the advantages associated with the translation and cultural adaptation of instruments developed and already validated in other countries, such as universalization of the measurements, ${ }^{11,19}$ the present authors searched the literature for an instrument with these characteristics. The Oliveira low back pain in young people questionnaire (OLBPYQ) was developed, validated and applied in various studies in Portugal ${ }^{20-22}$ and was shown to be a valid and trustworthy instrument (ICC $=0.89-0.97$ ). Thus the objective of this study was to translate the Oliveira questionnaire on low back pain in young people (OLBPYQ) into Brazilian Portuguese, make any necessary cultural adaptations, validate it, and evaluate its reproducibility (reliability) and internal consistency (stability).

\section{MATERIAL AND METHODS}

The following steps were carried out in this study: a) translation / cultural adaptation, b) validation of the contents, c) pre-test, d) evaluation of the reproducibility (test-retest), and e) evaluation of the internal consistency.

\section{The instrument}

The instrument was a self-reporting questionnaire with language accessible to the age-group to whom it was applied (10 - 18 years old), clear and objective, relying essentially on closed replies and quick to fill in (10 to 15 minutes). It concerned lumbago, a term including all complaints of low back pain (acute or chronic), which can irradiate to the backside and legs, lasting a minimum of 24 hours. . $^{12,21}$

It intended to answer the following questions: sociodemographic variables (age, gender) and psychosocial variables as related to certain living habits, such as level of physical activity and smoking habits. With respect to lumbago, the questions were: occurrence of low back pain; age when first felt low back pain (years); frequency of pain episodes in last three months; time since the start of the complaints; intensity of the low back pain (measured using the visual analogical pain scale); location of the lumbago (body discomfort map); activities which aggravate the low back pain; need to have a consultation or follow treatment with a healthcare professional; and evolution of the lumbago since the worst moment in terms of pain, up to the moment of filling in the questionnaire.

\section{Participants and expert committee}

This study involved three steps with 15 to 18 year old young people from three schools in Florianópolis/ Brazil, none of them presented cognitive, physical and/or psychiatric problems that could prevent them from filling in the questionnaire, they were appointed by the directive teams of the schools and they all accepted to take part in the study.

Fifteen young people from school 1 took part in the pretest of the instrument (step 1), 40 from school 2 carried out the test-retest (step 2) and 679 from school 3 who indicated the internal consistency on filling in the OLBPYQ (step 3).

Three people with knowledge of the languages and cultures of the two countries (two Portuguese and one Brazilian) took part in the translation process, and 10 experts validated the contents (nine physical therapists and one special educator) with a mean of 22 years of professional experience (related to the application and validation of instruments, and who also had knowledge of low back pain).

\section{Ethical aspects}

The study was approved by the Ethics in Research Committee of the State University of Santa Catarina, Brazil, with the Certificate for the Presentation of Appreciation of Ethics (CAAE) $n^{\circ}$ 35004014.4.0000.0118/2014. All the participants signed a term of consent as did those responsible for them. The author of the original version of the questionnaire authorized the validation and use of the instrument.

\section{Translation, cultural adaptation, validation and pre-test}

The questionnaire was translated according to Hill \& Hill, ${ }^{23}$ where two people, one Brazilian and one Portuguese, with knowledge of both languages, translated the original version from European Portuguese into Brazilian Portuguese. Subsequently they evaluated the two translations and prepared a single version, keeping the fundamental characteristics of the concepts found in the original questionnaire. A third person, in this case Portuguese (with knowledge of Brazilian Portuguese) then retranslated the single version back to Portuguese from Portugal. The version adapted by the two translators was then compared to the retranslated version by the three evaluators.

For the cultural adaptation of the questionnaire from 
European Portuguese to the Brazilian idiom, in addition to evaluating the conceptual equivalence and understandability (elaborated during the translation), the validation and pretest contents of the new version were also carried out.

After translating the questionnaire, the contents were validated in order to verify the clarity, consistency and pertinence of the questions. ${ }^{23}$ The questionnaire was presented to 10 experts by a researcher in the form of a spreadsheet, with scores on an interval scale for each question and spaces for suggestions; each evaluator attributed a score from 1 to 5 (score 1 representing agreement without reserve, 2 agreement with the generality but with some suggestions for alterations, 3 not agreeing with the form with which the item was formulated and proposing substantial alterations so as to maintain the item in the questionnaire, 4 disagreeing completely with the inclusion of the item in the questionnaire, and 5 no opinion), and proposed suggestions or changes whenever relevant. The evaluators were blinded with respect to the other experts to avoid influencing the replies.

Based on the evaluations provided, the initial version of the questionnaire was altered to a certain extent to provide a second version, which was submitted to the same experts.
The final version of the questionnaire as approved by the experts was submitted to a pre-test with 15 young people from school 1 to detect any difficulties and provide opinions about the instrument (step 1). The young people were divided into three groups and received explanations about the objectives of the study and guidance about how to fill in the questionnaire (with spaces between the questions for suggestions). After filling it in, the groups were interviewed by a researcher other than the one who handed out the questionnaires (to avoid influencing the replies) and the qualitative impressions of the young people were noted down.

\section{Reproducibility and internal consistency}

In order to estimate its reproducibility, the questionnaire was applied twice to 40 young people (school 2, step 2), who filled in the form with questions related to identification (date of birth, gender and profession) and received information about filling in the questionnaire and the objectives of the survey. The retest procedure was explained after concluding the initial test, minimizing the opportunity to memorize the replies. The retest was applied 7 days after the first test by one researcher and analyzed by another, to prevent

Table 1 - Characteristics of the young people

\begin{tabular}{|c|c|c|c|c|c|c|}
\hline Dimension - Question & $\begin{array}{l}\text { Majority } \\
\text { reply }\end{array}$ & $\begin{array}{l}\text { Young people } \\
\text { School } 1^{\mathrm{a}}\end{array}$ & $\begin{array}{l}\text { Majority } \\
\text { reply }\end{array}$ & $\begin{array}{l}\text { Young people } \\
\text { School } 2^{\mathrm{b}}\end{array}$ & $\begin{array}{l}\text { Majority } \\
\text { reply }\end{array}$ & $\begin{array}{l}\text { Young people } \\
\text { School } 3^{c}\end{array}$ \\
\hline Age - Average $\pm S D$ & 16 years & $16.13 \pm 0.64$ & 17 years & $16.45 \pm 0.93$ & 16 years & $16.23 \pm 0.9$ \\
\hline Girls - n (\%) & - & $9(60 \%)$ & - & $24(60 \%)$ & - & $426(62.7 \%)$ \\
\hline Boys - n (\%) & - & $6(40 \%)$ & - & $16(40 \%)$ & - & $253(37.3 \%)$ \\
\hline Menarche - n (\%) & $\begin{array}{l}\text { Age } 13 \\
\text { years }\end{array}$ & $4(26.67 \%)$ & $\begin{array}{l}\text { Age } 12 \\
\text { years }\end{array}$ & $10(25 \%)$ & $\begin{array}{l}\text { Age } 12 \\
\text { years }\end{array}$ & $116(17.1 \%)$ \\
\hline Profession - n (\%) & No & $12(80 \%)$ & No & $31(77.5 \%)$ & No & $550(81 \%)$ \\
\hline 1. Physical activity at school $n(\%)$ & Yes & $13(86.67 \%)$ & Yes & $36(90 \%)$ & Yes & $562(82.8 \%)$ \\
\hline \multicolumn{7}{|l|}{ 2. Other activities (last 3 months) } \\
\hline TV time per day - Average $\pm S D$ & Minutes & $144 \pm 84.24$ & Minutes & $195.75 \pm 121.71$ & Minutes & $193.04 \pm 154.87$ \\
\hline Computer/similar time - Average \pm SD & Minutes & $696 \pm 458.52$ & Minutes & $378.75 \pm 265.97$ & Minutes & $628.02 \pm 391.48$ \\
\hline Do you go to school on foot - $\mathrm{n}(\%)$ & Yes & $8(53.33 \%)$ & Yes & $21(52.5 \%)$ & No & $422(62.2 \%)$ \\
\hline Physical activity out of school - $n(\%)$ & Yes & $8(53.33 \%)$ & Yes & $22(55 \%)$ & Yes & $405(59.6 \%)$ \\
\hline \multicolumn{7}{|l|}{ 3. Lumbago } \\
\hline Low back pain at the moment $-\mathrm{n}(\%)$ & No & $11(73.33 \%)$ & No & $30(75 \%)$ & No & $494(72.8 \%)$ \\
\hline Low back pain at some time $-\mathrm{n}(\%)$ & Yes & $10(66.67 \%)$ & Yes & $35(87.5 \%)$ & Yes & $502(73.9 \%)$ \\
\hline 4. Pain in last 3 months - $\mathrm{n}(\%)$ & Yes & $8(53.33 \%)$ & Yes & $28(70 \%)$ & Yes & $392(57.7 \%)$ \\
\hline${ }^{*}$ Pain intensity $(0-10)-\mathrm{n}(\%)$ & Level 5 & $4(40 \%)$ & Level 4 & $7(20 \%)$ & Level 4 & $86(17.13 \%)$ \\
\hline $\begin{array}{l}\text { *Pain in other area whilst suffering } \\
\text { from lumbago? }\end{array}$ & Yes & $6(60 \%)$ & Yes & $16(45.71 \%)$ & Yes & $266(52.99 \%)$ \\
\hline
\end{tabular}

a 15 young people (questionnaire testing); ${ }^{\mathrm{b}} 40$ young people (questionnaire test-retest); ${ }^{\mathrm{c}} 679$ young people (evaluation of the internal consistency of the questionnaire)

* considering only young people who had suffered from low back pain at some point 
influencing the results.

The internal consistency of the questionnaire was verified from the replies of 679 young people (school 3 , step $3)$.

\section{Statistical analysis}

The descriptive analysis was carried out through the mean, standard deviation and frequency distribution of the data. The semantic analysis of the contents was carried out according to the content validity coefficient as proposed by Hernandez-Nieto. ${ }^{24}$

The reproducibility was evaluated using the test-retest with an interval of seven days, to observe agreement between the measurements, being estimated using the intra-class correlation coefficient and by Spearman's correlation coefficient (for the variables with some difference between the test and retest). The internal consistency was analyzed by means of Cronbach's alpha.

A definition of consistency was used to analyze the type $C$ intra-class correlation coefficient, adopting the mixed bidirectional effects model in which the effects of the people are randomized and those of the measurements are fixed. For single measurements the estimator was the same, whether the effect of interaction was present or not, whereas for mean measurements, the estimate was calculated considering that the effect of interaction was absent.

Intra-class correlation (ICC) indexes below 0.50 are considered unacceptable by the literature, values between 0.50 and 0.69 are acceptable, 0.70 to 0.79 are considered good, 0.80 to 0.89 are very good and above 0.90 excellent. ${ }^{25}$ Values for Spearman's correlation coefficient (SCC) between -1 and 1 classify the instrument as reproducible. George and Mallery ${ }^{26}$ classified the Cronbach's alpha as follows: above 0.9 excellent, 0.8 to 0.9 good, 0.7 to 0.8 acceptable, 0.6 to 0.7 questionable, 0.5 to 0.6 poor and below 0.5 unacceptable. The analyses were carried out using the Statistical Package for Social Sciences (SPSS) software, version 20.0 , adopting a $5 \%$ level of significance.

\section{RESULTS}

The majority of young people who took part in the test were female, non-smokers and with no profession and they were all students. The other characteristics were described in Table 1.

\section{Cross-cultural adaptation}

The process of cultural adaptation produced the Brazilian version of the OLBPYQ [Appendix 1: original and Brazilian version (http://www.actamedicaportuguesa.com/revista/ index.php/amp/article/view/8270/5201)]. In the translation phase the original version was modified by the translators, and after re-translation to the language of origin, great similarity and equivalence with the original version was observed, and the questionnaire was considered suitable. Terms and expressions having greater familiarity for young Brazilians were used in the final version of the translation (Table 2).

The translated version of the questionnaire was sent to the experts with five dimensions - dimension 1: personal data (5 questions), dimension 2: physical activity at school (1 question), dimension 3: physical activity out of school (6 questions), dimension 4: occurrence of low back pain (2 questions) and dimension 5: low back pain in the last 3 months (11 questions). Table 3 shows the evaluations and the means of the scores attributed by the experts with respect to the construct contents. The experts evaluated the clarity and pertinence of the questions and, after a few corrections and suggestions, the modified instrument was again sent for analysis and considered suitable and valid, with a mean of 1.3 (agree without reserve) and coefficient of validity of $94 \%$.

The instrument was then tested with young people, who suggested some modifications, improving the understanding and making it more succinct, consisting of 5 dimensions and 19 questions. All the modifications were approved by the author of the original version.

Table 2 - Modifications carried out during the translation process

\begin{tabular}{|c|c|c|}
\hline $\begin{array}{l}\text { Original } \\
\text { (item or word Portuguese from Portugal) }\end{array}$ & $\begin{array}{l}\text { Modification, final translation version } \\
\text { (Brazilian Portuguese) }\end{array}$ & Modification, final translation version \\
\hline 5 dimensions and 25 questions & 5 dimensions and 25 questions & 5 dimensions and 25 questions \\
\hline $\begin{array}{l}\text { Q } 1.1 \text { Se és rapariga: Idade do } 1^{\circ} \text { Período } \\
\text { Menstrual }\end{array}$ & $\begin{array}{l}\text { Q 1.1 Se és do sexo feminino qual a } \\
\text { idade da primeira menstruação? }\end{array}$ & $\begin{array}{l}\text { Q } 1.1 \text { If you are a female, how old were } \\
\text { you when you had your first menstrual } \\
\text { period? }\end{array}$ \\
\hline $\begin{array}{l}\text { Q } 3.4 \text { Nos últimos } 3 \text { meses, tuas } \\
\text { deslocações de casa para a escola e de } \\
\text { escola para casa, foram a andar a pé: }\end{array}$ & $\begin{array}{l}\text { Q } 3.4 \text { Nos últimos } 3 \text { meses, teus } \\
\text { deslocamentos de casa para a } \\
\text { escola e da escola para casa, foram } \\
\text { caminhando? }\end{array}$ & $\begin{array}{l}\text { Q } 3.4 \text { In the last } 3 \text { months did you go from } \\
\text { home to school and from school to home } \\
\text { on foot? }\end{array}$ \\
\hline Q 3.6... saltar à corda com os amigos & Q 3.6... pular corda com os amigos & Q 3.6... skipping rope with your friends \\
\hline $\begin{array}{l}\text { Q } 5.11 \text { Por vezes senti dores nas costas, } \\
\text { mas mais ligeiras. }\end{array}$ & $\begin{array}{l}\text { Q } 5.11 \text { Por vezes senti dores nas } \\
\text { costas, mas passageiras. }\end{array}$ & $\begin{array}{l}\text { Q } 5.11 \text { Sometimes l've had backache, but } \\
\text { it did not last long. }\end{array}$ \\
\hline $\begin{array}{l}\text { Use of words: } \\
\text { actividade física } \\
\text { jogos electrónicos } \\
\text { directo }\end{array}$ & $\begin{array}{l}\text { Substitutions: } \\
\text { atividade física } \\
\text { jogos eletrônicos } \\
\text { direto }\end{array}$ & $\begin{array}{l}\text { Words / Substitutions } \\
\text { physical activity } \\
\text { electronic games } \\
\text { direct }\end{array}$ \\
\hline
\end{tabular}


Table 3 - Analysis by the experts (suggestions and coefficient of validity) and pre-test with young people (qualitative evaluation)

\begin{tabular}{|c|c|c|c|}
\hline Final translated version & & Evaluation by the experts & Evaluation by the Young people \\
\hline Dimension & $\begin{array}{l}\text { Score/Mean } \\
\text { (SD) }\end{array}$ & Corrections/Suggestions & \\
\hline $\begin{array}{l}1 \text { - Personal data } \\
\text { Questions } 1 \text { to } 5\end{array}$ & $\begin{array}{c}2.3 \\
(0.48)\end{array}$ & $\begin{array}{l}\text { - Change the pronoun in Portuguese. } \\
\text { - Q3 include the alternatives: don't want } \\
\text { to reply/don't know. } \\
\text { - Leave the nr. of cigarettes as an open } \\
\text { answer. } \\
\text { - Q4 remove the alternative of student } \\
\text { since it is obligatory. } \\
\text { - Q5 remove the question about race/ } \\
\text { ethnic group. }\end{array}$ & No suggestions. \\
\hline $\begin{array}{l}2 \text { - Physical activity at school } \\
\text { Question } 1\end{array}$ & $\begin{array}{c}1.2 \\
(0.4)\end{array}$ & Suitable - no suggestions. & No suggestions. \\
\hline $\begin{array}{l}\text { 3- Physical activities out of } \\
\text { school } \\
\text { Questions } 1 \text { to } 6\end{array}$ & $\begin{array}{c}2.54 \\
(0.52)\end{array}$ & $\begin{array}{l}\text { - Change the dimension to "Other } \\
\text { activities". } \\
\text { - Use hours per day instead of hours per } \\
\text { week, since it is easier to remember. } \\
\text { - Q2 change to: did you use a computer, } \\
\text { tablet (or apparatus with similar } \\
\text { functions)? } \\
\text { - Q3 change whole hours to: how long } \\
\text { on average. Separate weekdays from } \\
\text { weekends since the sleeping times are } \\
\text { different. } \\
\text { - Q4 Change to: do you go from home to } \\
\text { school and from school to home on foot? } \\
\text { - Q5 and Q6 turn them into one question. }\end{array}$ & No suggestions. \\
\hline $\begin{array}{l}4 \text { - Occurrence of backache } \\
\text { Questions } 1 \text { and } 2\end{array}$ & $\begin{array}{l}1.18 \\
(0.4)\end{array}$ & Suitable - no suggestions. & No suggestions. \\
\hline $\begin{array}{l}\mathbf{5} \text { - Low back pain in the last } 3 \\
\text { months } \\
\text { Questions } 1 \text { to } 11\end{array}$ & $\begin{array}{c}2.0 \\
(0.63)\end{array}$ & $\begin{array}{l}\text { - Many questions seem to be repetitive. } \\
\text { - Recommendation to make the } \\
\text { questionnaire as short as possible. }\end{array}$ & $\begin{array}{l}\text { - Transform the closed alternatives } \\
\text { with numbers of times into open } \\
\text { questions - makes it easier to } \\
\text { reply. } \\
\text { - Q5 remove this question since it } \\
\text { is very difficult to give a reply to. } \\
\text { - Q6 suggestion to put the figure } \\
\text { with the names on the locations of } \\
\text { each region. } \\
\text { - Q8 remove this question since it } \\
\text { appears to repeat an earlier one. } \\
\text { - Q11 remove this question since it } \\
\text { is very difficult to give a reply to. }\end{array}$ \\
\hline $\begin{array}{l}\text { Total: } 5 \text { dimensions and } 25 \\
\text { questions }\end{array}$ & $\begin{array}{l}1.97 \\
(0.51)\end{array}$ & 5 dimensions and 22 questions & 5 dimensions 19 questions \\
\hline
\end{tabular}

\section{Internal consistency and reproducibility}

Table 4 shows the results obtained in the analysis of reproducibility and internal consistency.

With respect to reproducibility, the values for ICC went from 0.512 = acceptable to $1=$ excellent, and for Spearman's correlation coefficient they went from 0.525 to 1 (Table 5), classifying the instrument as reproducible. As a measure of the internal consistency for the variables that measure pain, the instrument had a Cronbach's alpha $=0.757$, which is considered acceptable.

According to the measurements calculated, the instrument is considered consistent and reproducible.

\section{DISCUSSION}

The results of this study indicated that the Brazilian version of the OLBPYQ questionnaire showed valid and reliable cultural adaptation. Although the instrument was subjected to some modifications during the translation, validation and testing steps, no difficulties were encountered in this process. The modifications carried out served to adequate the expressions and reach equivalence, while at the same time maintaining the attributes and precision of the original instrument. The adaptation of the questionnaire is an important step, since some of the original questions are not always applicable in other cultures. . $^{3,13}$

The Oliveira questionnaire was chosen due to the fact 
that it had been used in various studies in Portugal, ${ }^{20-22}$ and attended to the need to raise data concerning symptoms of low back pain and associated risk factors, and it also presented a clear definition of lumbago. In a survey carried out to identify other studies about low back pain, only 81 out of 1200 documents were identified which provided a clear definition of the symptom, and the lack of such standardization makes it difficult to confront the present data with data from other studies. ${ }^{12}$ The majority of the questionnaires used in standardized (validated and applied in different countries) studies on low back pain were those evaluating disability, fear or the catastrophizing of patients already diagnosed with low back pain, ${ }^{27,28}$ since identifying the patient's behaviors and limitations helps in the choice of treatment ${ }^{29}$ aimed at reducing the chronicity, reestablishing the health and returning to normal activities. ${ }^{5,6,27}$ However another approach reinforces the importance of identifying the risk factors in young people and adopting primary care, instead of only focusing on policies and treatments during adulthood and in already triggered cases. ${ }^{6,13,27,30}$ The OLBPYQ is thus aimed at detecting the problem as soon as the patient mentions low back pain, approaching questions such as occurrence, frequency, intensity and the risk factors which, according to the literature, point in the direction of Table 4 - Reliability (Test - Retest) and internal consistency of the Oliveira Questionnaire on Low Back Pain in Young people

\begin{tabular}{|c|c|c|c|c|c|}
\hline \multirow{3}{*}{ Dimension - Question } & \multirow{3}{*}{$\begin{array}{l}\text { Type of } \\
\text { scale }\end{array}$} & \multicolumn{3}{|c|}{ Reliability } & \multirow{3}{*}{$\begin{array}{c}\text { Internal } \\
\text { consistency } \\
\text { Cronbach's } \\
\alpha\end{array}$} \\
\hline & & \multicolumn{3}{|c|}{ Interclass correlation coefficient (ICC) } & \\
\hline & & ICC & IC (95\%) & Classification & \\
\hline \multicolumn{6}{|l|}{ 1. Menarche, cigarette and profession } \\
\hline Q1.1 - Menarche (age) & QTD & 1 & --- & EXC & 1 \\
\hline Q1.2 - Cigarette (smoke) & QLN & & --- & & \\
\hline Q1.2.1 - Age when started & QTD & & --- & & \\
\hline Q1.2.2 - Number per week & & & --- & & \\
\hline Q1.3 - Profession & QLN & 1 & --- & EXC & 1 \\
\hline Q1.3.1 - Which? & QLN & & --- & & \\
\hline \multicolumn{6}{|l|}{ 2. Physical activity at school } \\
\hline Q2.1 - Physical activity in the physical education class? & QLN & 1 & --- & EXC & 1 \\
\hline Q2.1.1 - Time per week & QTD & 1 & --- & EXC & 1 \\
\hline If not, why not & & & --- & & \\
\hline \multicolumn{6}{|l|}{ 3. Other activities (cons. 3 months) } \\
\hline Q3.1 - Time (hs/day) TV & QTD & 0.974 & $(0.951 ; 0.986)$ & EXC & 0.987 \\
\hline Q3.2 - Time (hs/day) comp./similar & QTD & 0.984 & $(0.970 ; 0.991)$ & EXC & 0.992 \\
\hline Q3.3.1 - Time sleeping (hs/night weekdays) & QTD & 0.840 & $(0.718 ; 0.912)$ & EXC & 0.913 \\
\hline Q3.3.2 - Time sleeping (hs/night weekends) & QTD & 0.915 & $(0.846 ; 0.954)$ & EXC & 0.956 \\
\hline Q3.4 - Go from home to school on foot & QLN & 0.964 & $(0.932 ; 0.981)$ & EXC & 0.981 \\
\hline Q3.4.1 - Time (hs/week) & QTD & 0.959 & $(0.925 ; 0.978)$ & EXC & 0.979 \\
\hline Q3.5 - Physical activity out of school & QLN & 1 & --- & EXC & 1 \\
\hline \multicolumn{6}{|l|}{ 4. Lumbago } \\
\hline Q4.1 - Low back pain at the moment & QLN & 0.512 & $(0.243 ; 0.709)$ & ACE & 0.678 \\
\hline Q4.2 - Low back pain at any time & QLN & 1 & --- & EXC & 1 \\
\hline Q4.2.1 - Age & QTD & 1 & --- & EXC & 1 \\
\hline \multicolumn{6}{|l|}{ 5. Lumbago in the last 3 months } \\
\hline Q5.1 - Pain in the last 3 months & QLN & 1 & --- & EXC & 1 \\
\hline Q5.2 - How many times/ don't know & QTD & 0.978 & $(0.959 ; 0.988)$ & EXC & 0.989 \\
\hline Q5.3 - Pain intensity & QLO & 0.990 & $(0.981 ; 0.995)$ & EXC & 0.995 \\
\hline Q5.4 - Duration of worst episode/ don't know & QTD & 0.952 & $(0.912 ; 0.974)$ & EXC & 0.976 \\
\hline Q5.5 - Pain in other region during lumbago & QLN & 1 & --- & EXC & 1 \\
\hline Q5.6 - Pain: ativity & QLN & 1 & --- & EXC & 1 \\
\hline Q5.7 - Did you consult with a professional & QLN & 1 & --- & EXC & 1 \\
\hline Q5.8 - Treatment of low back pain & QLN & 1 & --- & EXC & 1 \\
\hline
\end{tabular}

Scale - QLN: qualitative nominal; QLO: qualitative ordinal; QTD: quantitative discreet. ICC classification - NA: not acceptable; ACE: acceptable; VG: very good; EXC: excellent; --- : information could not be calculated 
Table 5 - Spearman's correlation coefficient

\begin{tabular}{lc}
\hline Variable & $\begin{array}{c}\text { Sperman's } \\
\text { correlation }\end{array}$ \\
\hline TV time & 0.974 \\
Computer/ similar time & 0.954 \\
Sleeping time on weekdays & 0.803 \\
Sleeping time at weekends & 0.933 \\
Displacement on foot & 0.964 \\
Displacement time & 0.969 \\
Low back pain now & 0.525 \\
How many times low back pain in the last & 1 \\
three months & 0.987 \\
Low back pain intensity & \\
\hline
\end{tabular}

the outcome. As in other studies, the pain intensity in young people was detected through a visual analogical scale which has been considered valid and reliable. ${ }^{31,32}$ Low pain intensity and frequency should receive attention, since lack of care in these cases has shown a tendency to chronicity. ${ }^{7,9}$ It is known that the majority of people with lumbago deal with it themselves, ${ }^{29}$ whereas the main preventative measures reside in the approach of seeking professional help and treatment as soon as the first symptoms appear. ${ }^{7}$

The OLBPYQ is also aimed at generating data capable of fostering greater discussion concerning the associated risk factors, and thus, as suggested by other studies, questions concerning physical activity, ${ }^{21,33,34}$ time spent playing computer games/ watching videos and TV, ${ }^{21,32,34}$ gender, ${ }^{21,34}$ sleeping time ${ }^{31}$ and others, were included.

The Oliveira questionnaire on low back pain in young people showed adequate reliability. The 1-week interval between the test and retest contributed to this result, since this period is considered suitable to prevent the students from remembering the replies they gave in the previous week, and at the same time not presenting changes in their habits or behaviors that could interfere with their replies. ${ }^{18,35}$ Decreased reliability has been reported with an increase in the number of days between the tests. ${ }^{17}$ The question with the least reliability in the Oliveira questionnaire referred to low back pain during the moment of filling it in. Although a 1-week period was considered adequate for the retest, it was sufficient time for the pain complaints of young people to undergo modifications, since the majority of young people reported more passing complaints. ${ }^{21}$ Contrarily to the others, ${ }^{18,35,36}$ the questions for this instrument involving the temporal perception of an activity presented excellent reliability. This difference between the studies could be related to the motivation of young people to fill in the questionnaire, since an individual's subjective perception as related to time, depends on factors such as interest and satisfaction. ${ }^{36}$ According to those evaluated, the application of questionnaires during more theoretical classes, as in this study, tends to motivate students. The excellent value for reliability attributed to the questions involving temporal recall by the young people could also be related to the fact that the period was restricted to the last three months, conferring less memory bias.

With respect to internal consistency, the Oliveira questionnaire obtained a 0.75 Cronbach's Alpha for the questionnaire itself and 0.68 to 1 for the questions, which show the questionnaire has stability, that is, there is variation in the replies of young people but not inconsistency in the questions used in the instrument.

The OLBPYQ can serve as an instrument to evaluate low back pain in young people, to be applied in schools, clinics and in surveys, since the language is accessible, it is easy to fill in and helps raise the factors associated with the symptom. Some methodological care involves a prior explanation of the instrument to young people. Maintenance of the 3-month period for questions involving the recall of events is recommended, thus decreasing errors due to memory bias over longer periods. It is recommended to check the period of data gathering (school term or school holidays) for a better contextualization of the symptom.

This study had some limitations: the size of our sample for the test-retest stage was suitable for statistical analysis, but we are not sure if a larger sample could give us better results; the values of the repeatability and reliability of the questionnaire depended on the memory and motivation of young people to answer it; the difficulty in finding validated instruments with the same definition of low back pain made the comparison of this questionnaire with others harder. Moreover, verification of convergent validity can be hampered when there are no validated questionnaires in the same language or even when the other existing instruments refer to different concepts or have a different focus.

\section{CONCLUSIONS}

The cultural adaptation of the Brazilian version of the OLBPYQ questionnaire was valid and reliable, with good repeatability and stability. Its use can be recommended in studies with young people to evaluate questions related to lumbago and associated risk factors. The standardization of this questionnaire is recommended by adapting it to other languages/cultures, standardizing the data and providing support for prevention and treatment.

\section{ACKNOWLEDGMENTS}

The author of the original version of the questionnaire authorized the validation and use of the instrument.

\section{PROTECTION OF HUMANS AND ANIMALS}

The study was approved by the Ethics in Research Committee of the State University of Santa Catarina, Brazil, with the Certificate for the Presentation of Appreciation of Ethics (CAAE) n 35004014.4.0000.0118/2014.

\section{DATA CONFIDENTIALITY}

The authors declare having followed the protocols in use at their working center regarding patients' data publication. All the participants signed a term of consent as did those responsible for them. 


\section{CONFLICTS OF INTEREST}

The authors declare no conflicts of interest. No funding was obtained for this study.

\section{REFERENCES}

1. Smith AJ, O'Sullivan PB, Beales D, Straker L. Back pain beliefs are related to the impact of low back pain in 17-year-olds. Phys Ther. 2012;92:1258-67.

2. Gore M, Sadosky A, Stacey BR, Tai K-S, Leslie D. The burden of chronic low back pain: clinical comorbidities, treatment patterns, and health care costs in usual care settings. Spine. 2012;37:E668-77.

3. Genevay S, Cedraschi C, Marty M, Rozenberg S, De Goumoens P, Faundez A, et al. Reliability and validity of the cross-culturally adapted French version of the Core Outcome Measures Index (COMI) in patients with low back pain. Eur Spine J. 2012;21:130-7.

4. Hoy D, Brooks P, Blyth F, Buchbinder R. The epidemiology of low back pain. Best Pract Res Clin Rheumatol. 2010;24:769-81.

5. Pinheiro J, Figueiredo P, Branco J, Ramos S, Ferreira L. Dor lombar crônica inespecífica e função: estudo clínico no âmbito de uma consulta de medicina física e de reabilitação. Acta Med Port. 2011;24:287-92.

6. Manchikanti L, Hirsch JA. What can be done about the increasing prevalence of low back pain and associated comorbid factors? Pain Manag. 2015;5:149-52.

7. Hestbaek L, Leboeuf-Yde C, Kyvik KO, Manniche C. The course of low back pain from adolescence to adulthood: eight-year follow-up of 9600 twins. Spine. 2006;31:468-72.

8. Pincus T, Kent P, Bronfort G, Loisel P, Pransky G, Hartvigsen J. Twentyfive years with the biopsychosocial model of low back pain-is it time to celebrate? A report from the twelfth international forum for primary care research on low back pain. Spine. 2013;38:2118-23.

9. Ferreira ML, Machado G, Latimer J, Maher C, Ferreira PH, Smeets RJ. Factors defining care-seeking in low back pain-a meta-analysis of population based surveys. Eur J Pain. 2010;14:747.e1-7.

10. Cardon G, Balague F. Low back pain prevention's effects in schoolchildren. What is the evidence? Eur Spine J. 2004;13:663-79.

11. de Barros EN, Alexandre NM. Cross-cultural adaptation of the Nordic musculoskeletal questionnaire. Int Nurs Rev. 2003;50:101-8.

12. de Vet HC, Heymans MW, Dunn KM, Pope DP, van der Beek AJ, Macfarlane GJ, et al. Episodes of low back pain: a proposal for uniform definitions to be used in research. Spine. 2002;27:2409-16.

13. Furtado R, Jones A, Furtado RN, Jennings F, Natour J. Validation of the Brazilian-Portuguese version of the Gesture Behavior Test for patients with non-specific chronic low back pain. Clinics. 2009;64:83-90.

14. Jackson $\mathrm{C}$, McLaughlin $\mathrm{K}$, Teti $\mathrm{B}$. Back pain in children: a holistic approach to diagnosis and management. J Pediatr Health Care. 2011;25:284-93.

15. Main CJ, George SZ. Psychologically informed practice for management of low back pain: future directions in practice and research. Phys Ther. 2011;91:820-4.

16. Schlademann $\mathrm{S}$, Meyer $\mathrm{T}$, Raspe $\mathrm{H}$. The test-retest reliability of a questionnaire on the occurrence and severity of back pain in a German population sample. Int J Public Health. 2008;53:96-103.

17. Geere JH, Geere JA, Hunter PR. Meta-analysis identifies Back Pain Questionnaire reliability influenced more by instrument than study design or population. J Clin Epidemiol. 2013;66:261-7.

18. Noll M, Tarrago Candotti C, Vieira A, Fagundes Loss J. Back pain and body posture evaluation instrument (BackPEI): development, content validation and reproducibility. Int J Public Health. 2013;58:565-72.

19. Beaton DE, Bombardier C, Guillemin F, Ferraz MB. Guidelines for the

\section{FUNDING SOURCES}

This research received no specific grant from any funding agency in the public, commercial, or not-for-profit sectors.

process of cross-cultural adaptation of self-report measures. Spine. 2000;25:3186-91.

20. Oliveira R. Estudo longitudinal sobre factores de risco biomorfológicos e psicossociais associados aos problemas músculo-esqueléticos da coluna lombar em adolescentes. Lisboa: Universidade Técnica de Lisboa; 2010.

21. Coelho L, Almeida V, Oliveira R. Lombalgia nos adolescentes: identificação de factores de risco psicossociais. Estudo epidemiológico na Região da Grande Lisboa. Rev Port Saúde Pública. 2005;23:81-90.

22. Oliveira R. A lombalgia nas crianças e adolescentes: Estudo epidemiológico na região da Grande Lisboa. Lisboa: Universidade Técnica de Lisboa; 1999.

23. Hill M, Hill A. Investigação por questionários. $2^{a}$ ed. Lisboa: Edições Sílabo; 2012.

24. Hernandez-Nieto RA. Contributions to statistical analysis. Mérida: Univ Los Andes; 2002.

25. Field A. Descobrindo a estatística usando SPSS (P. Lorí Viali, Trad.). Porto Alegre: Artmed; 2009.

26. George D, Mallery P. SPSS for Windows step by step: A simple guide and reference. $4^{\text {th }}$ ed. Canadian University College; 2003. [accessed 2016 jun 20]. Available from: http://wps.ablongman.com/wps/media/ objects/385/394732/george4answers.pdf.

27. Hill JC, Dunn KM, Main CJ, Hay EM. Subgrouping low back pain: a comparison of the STarT Back Tool with the Orebro Musculoskeletal Pain Screening Questionnaire. Eur J Pain. 2010;14:83-9.

28. Monteiro J, Faísca L, Nunes O, Hipólito J. Questionário de incapacidade de Roland Morris: adaptação e validação para a população portuguesa com lombalgia. Acta Med Port. 2010;23:761-6.

29. van Tulder M, Becker A, Bekkering T, Breen A, del Real MT, Hutchinson $A$, et al. Chapter 3. European guidelines for the management of acute nonspecific low back pain in primary care. Eur Spine J. 2006;15:S16991.

30. Maciel SC, Jennings F, Jones A, Natour J. The development and validation of a Low Back Pain Knowledge Questionnaire - LKQ. Clinics. 2009;64:1167-75.

31. Trigueiro MJ, Massada L, Garganta R. Back pain in Portuguese schoolchildren: prevalence and risk factors. Eur J Public Health. 2013;23:499-503.

32. Robbins M, Johnson IP, Cunliffe C. Encouraging good posture in school children using computers. Clin Chiropr. 2009;12:35-44.

33. Oliveira VC, Ferreira ML, Refshauge KM, Maher CG, Griffin AR, Hopper $\mathrm{JL}$, et al. Risk factors for low back pain: insights from a novel casecontrol twin study. Spine J. 2015;15:50-7.

34. Trevelyan FC, Legg SJ. Back pain in school children-where to from here? Appl Ergon. 2006;37:45-54.

35. Ayanniyi O, Mbada CE, Muolokwu CA. Prevalence and profile of back pain in Nigerian adolescents. Med Princ Pract. 2011;20:368-73.

36. Bejia I, Abid N, Bensalem K, Touzi M, Bergaoui N. Reproducibility of a low back pain questionnaire in Tunisian adolescents. Clin Rheumatol. 2006;25:715-20.

37. Vanti C, Monticone M, Ceron D, Bonetti F, Piccarreta R, Guccione AA, et al. Italian version of the Physical Therapy Patient Satisfaction Questionnaire: cross-cultural adaptation and psychometricpProperties. Phys Ther. 2013;93:911. 